

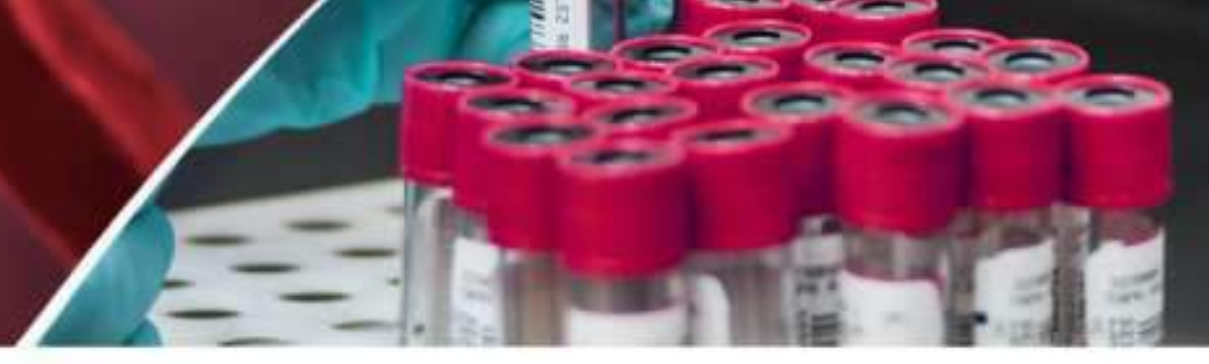

- Dapat terjadi banyak masalah dari kerja sistem imun yang keliru

atau tidak diharapkan.

- contohnya alergi, diabetes melitus, artritis reumatoid, penolakan jaringan transplantasi, AIDS (Acquired Immune De! ciency Syndrome), dan tumor ganas limfoma

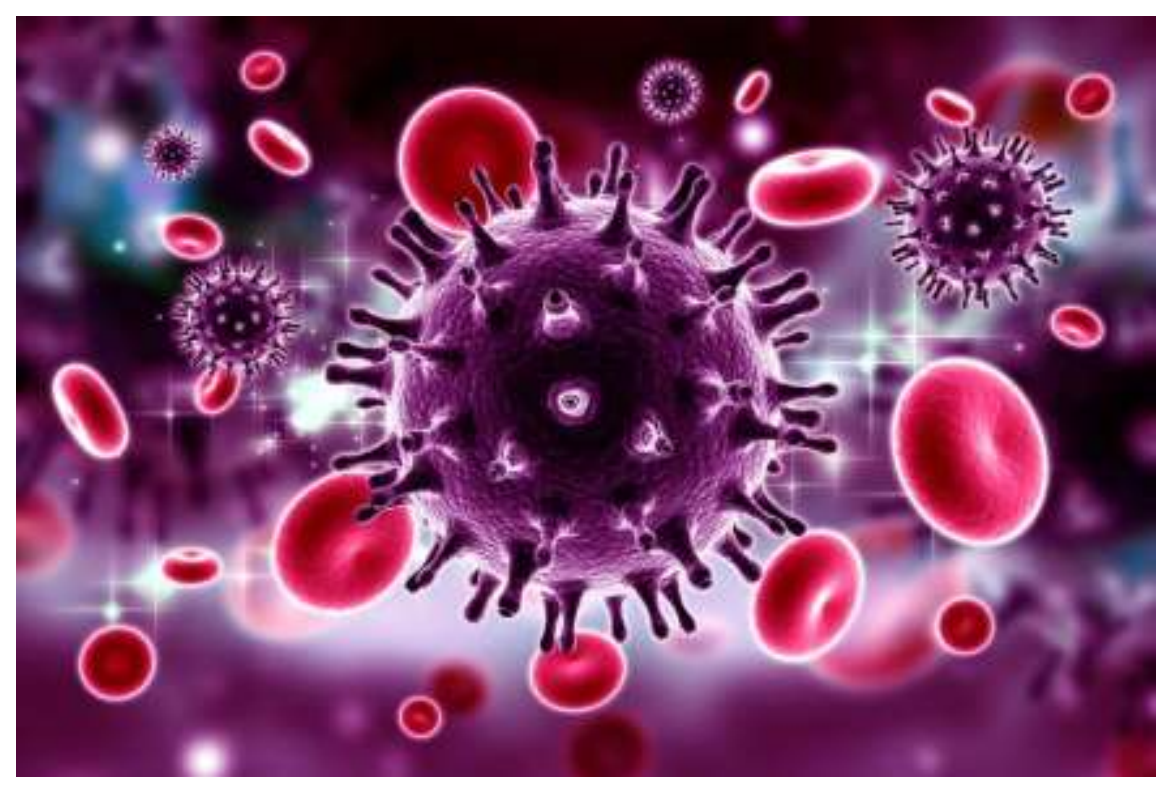


- AIDS : kelainan fungsi imun yang terjadi karena sel yang bekerja dalam sistem imun berkurang dalam jumlah maupun fungsinya

- Sel yang diserang Makrofage dan Sel T

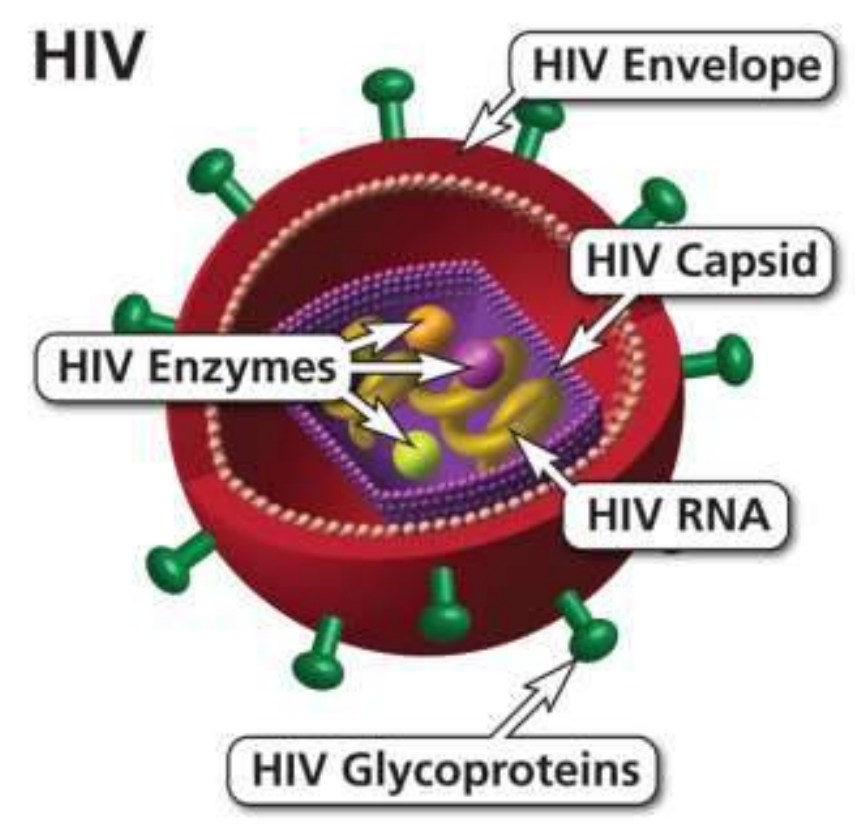




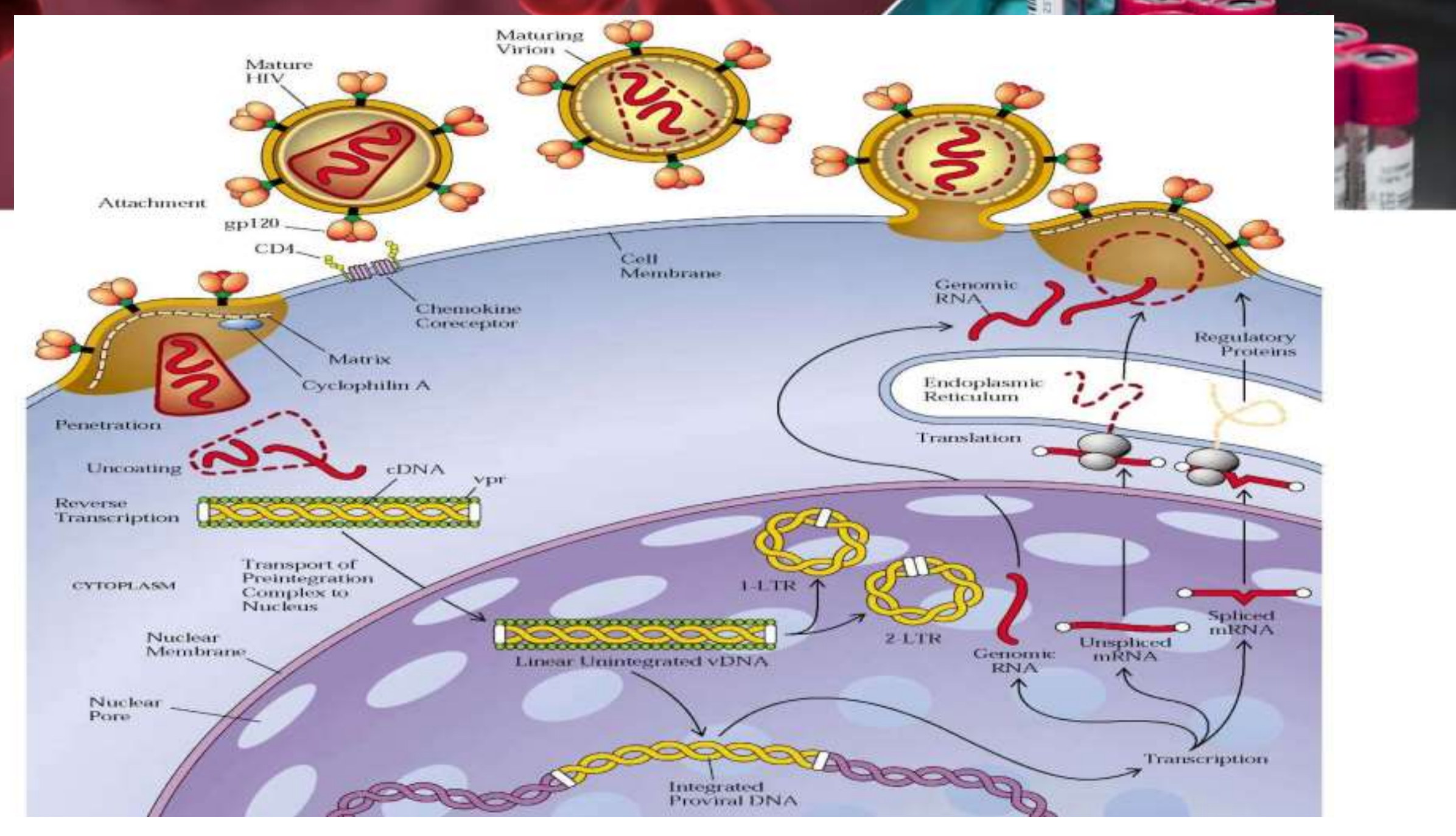




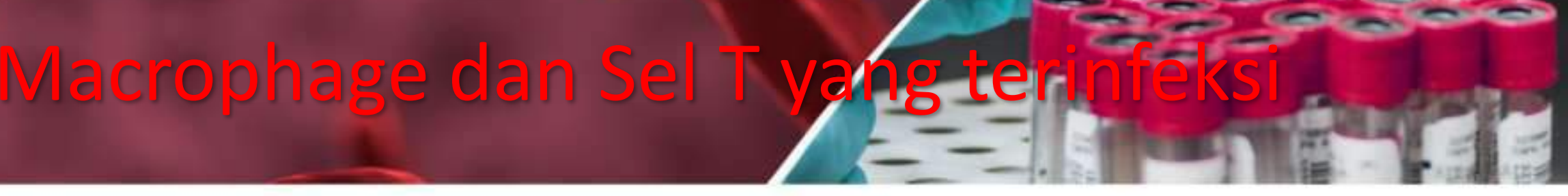

HIV Infection of Macrophages

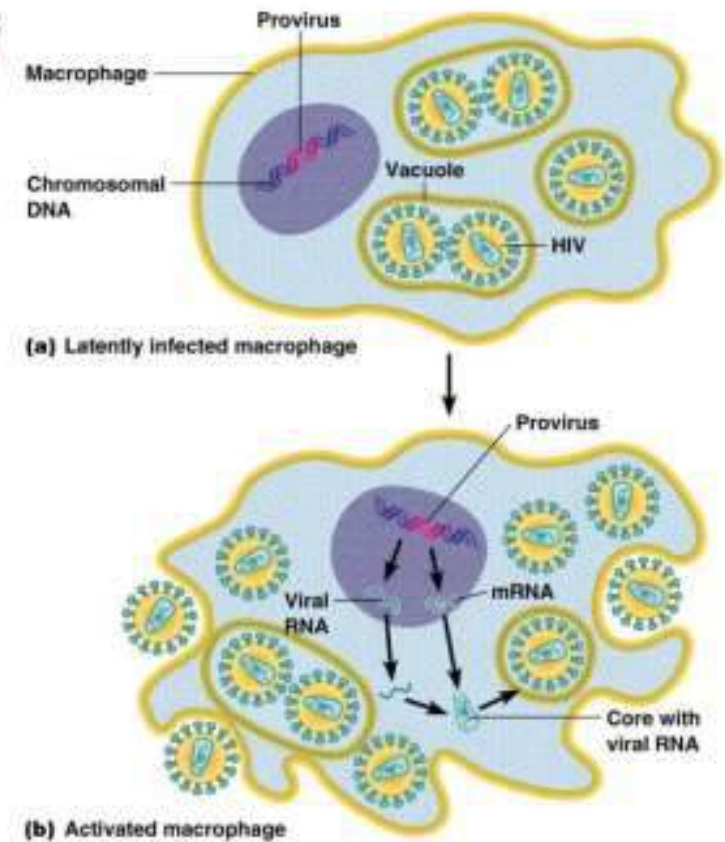

(b) Activated macrophage

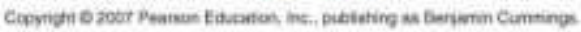

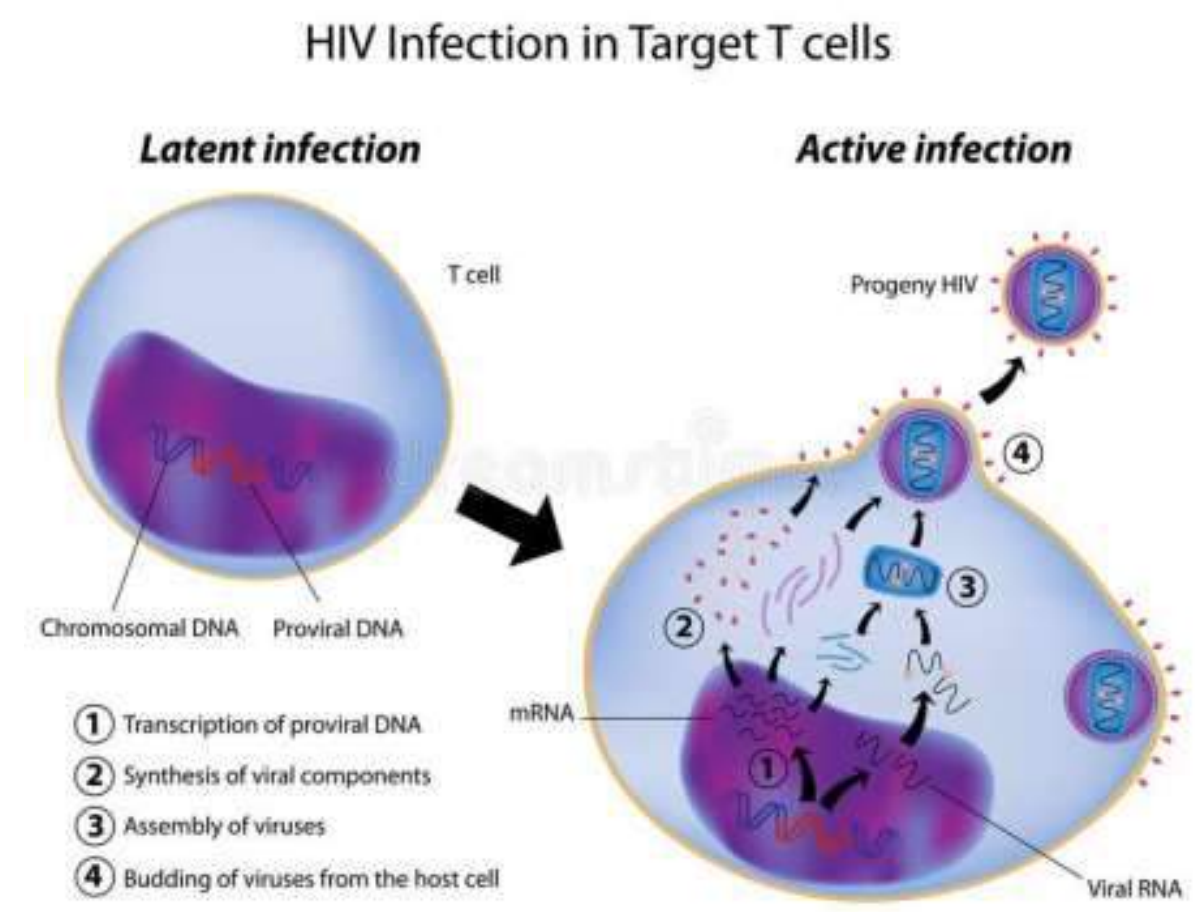




\section{Pneumocystis carinii pneumonia}

- Caused by Pnet(Pmocystis carinii

- Previously considered a protozoan

- Lacks the ergosterol ,which is essential component of most fungal membranes

- The disease was rare before the use of the immunosupressive drugs and onset of AIDS

- Currently is one of the most common opportunistic diseases of individuals infected with HIV-1 and $100 \%$ fatal if untreated

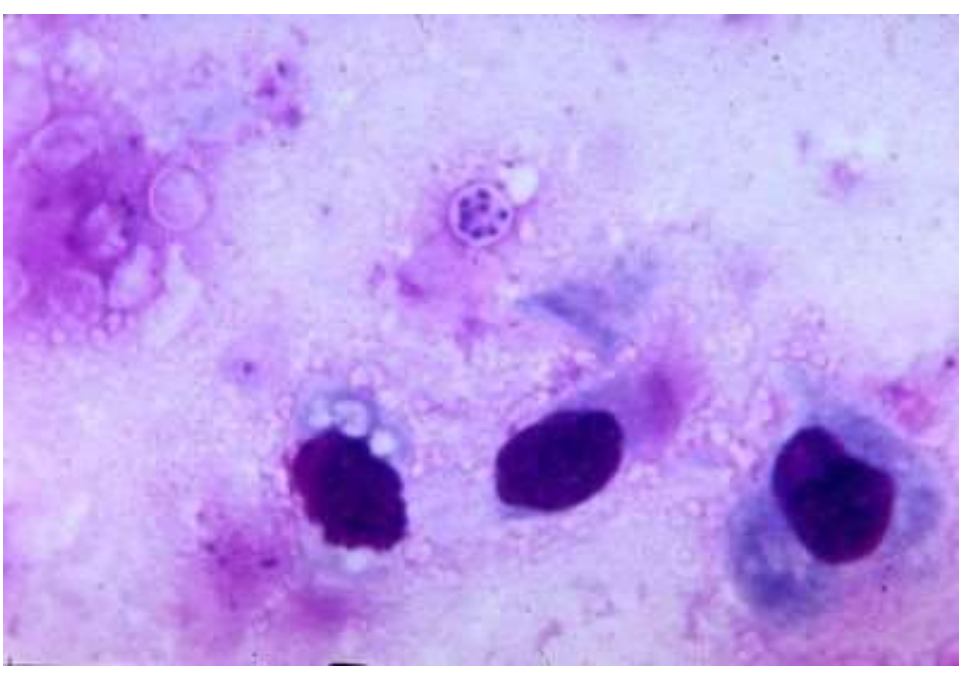




\section{contoh penyakit autoimun}

adalah penyakit artritis reumatoid, lupus eritematosis sistemik (SLE), tiroiditis, demam reumatik, glomerulonefritis, anemia hemolitika, miastenia gravis, multipel sklerosis, dan diabetes tipe I

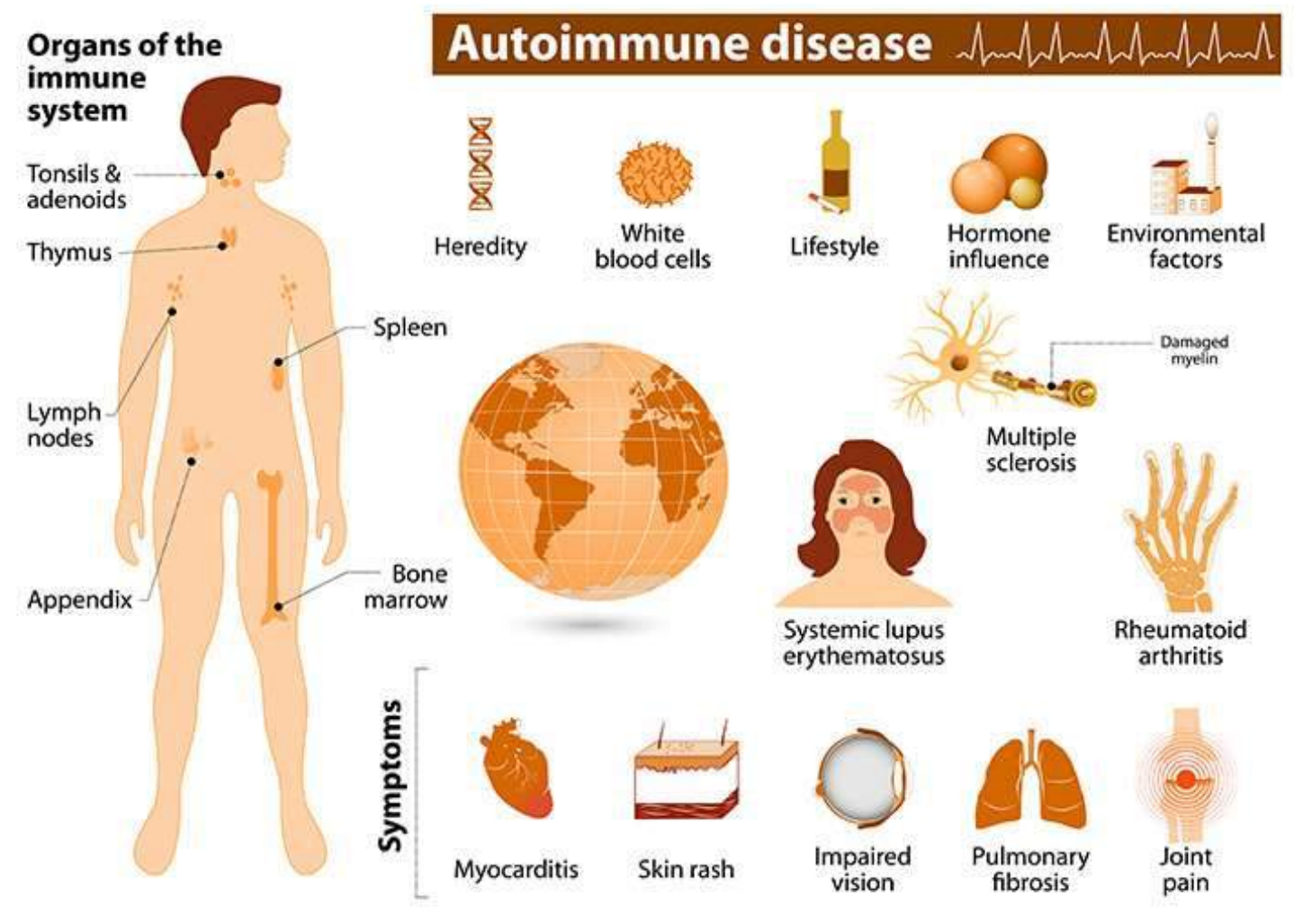




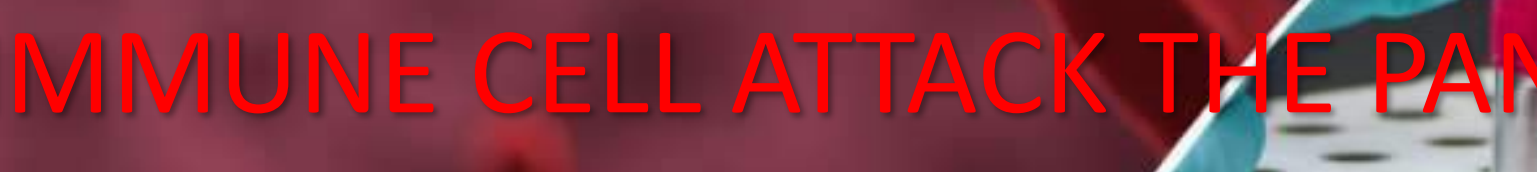

Diabetes: Why does the immune system attack the pancreas?

In type-1 diabetes, cells of the immune system attack the insulin-producing beta cells of the pancreas. Scientists have now found how this may happen.

\section{(PFI}

ECOLF FOLYTECHNIOUE
FDETALE DE LASANNE

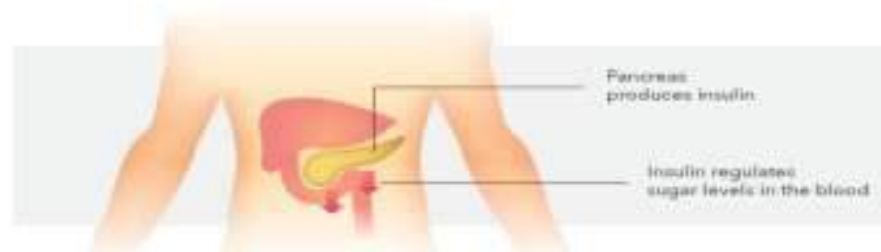

Healthy individual

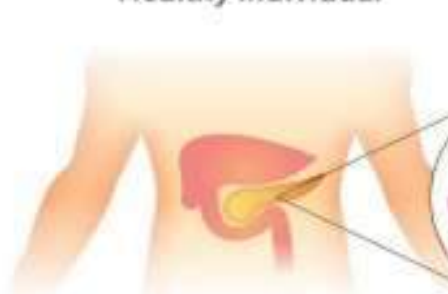

Patient with type-1 diabetes

T cells

Beta cells

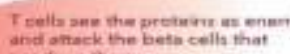

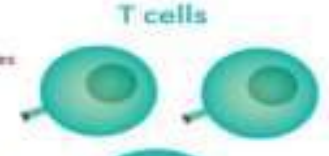

endritic cell

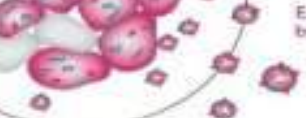

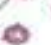

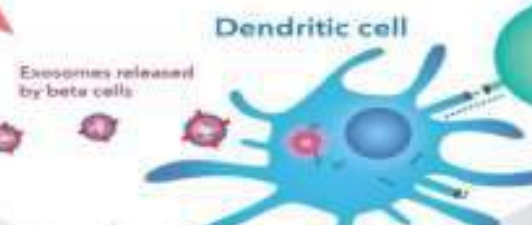
cells. 

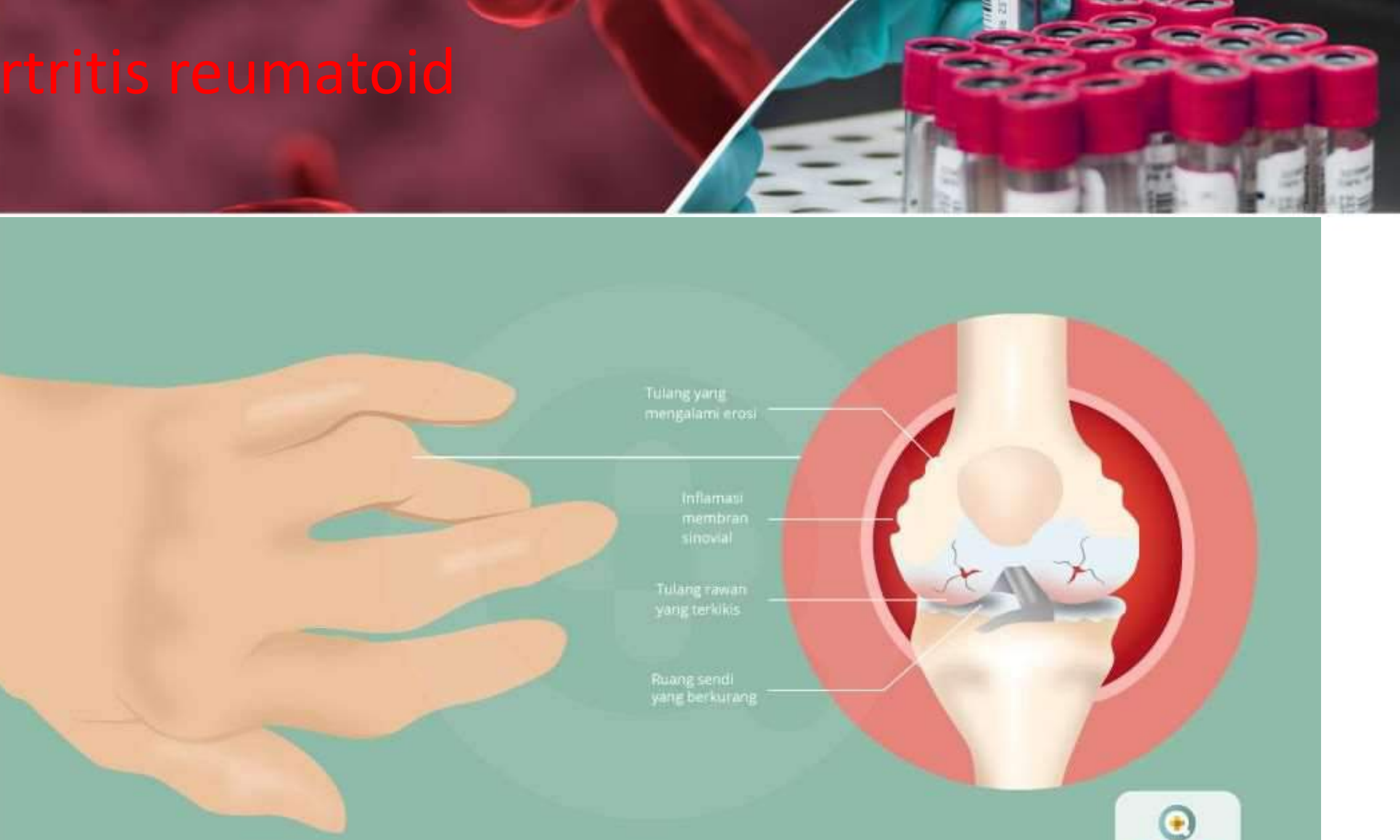

(a)

Sehato 


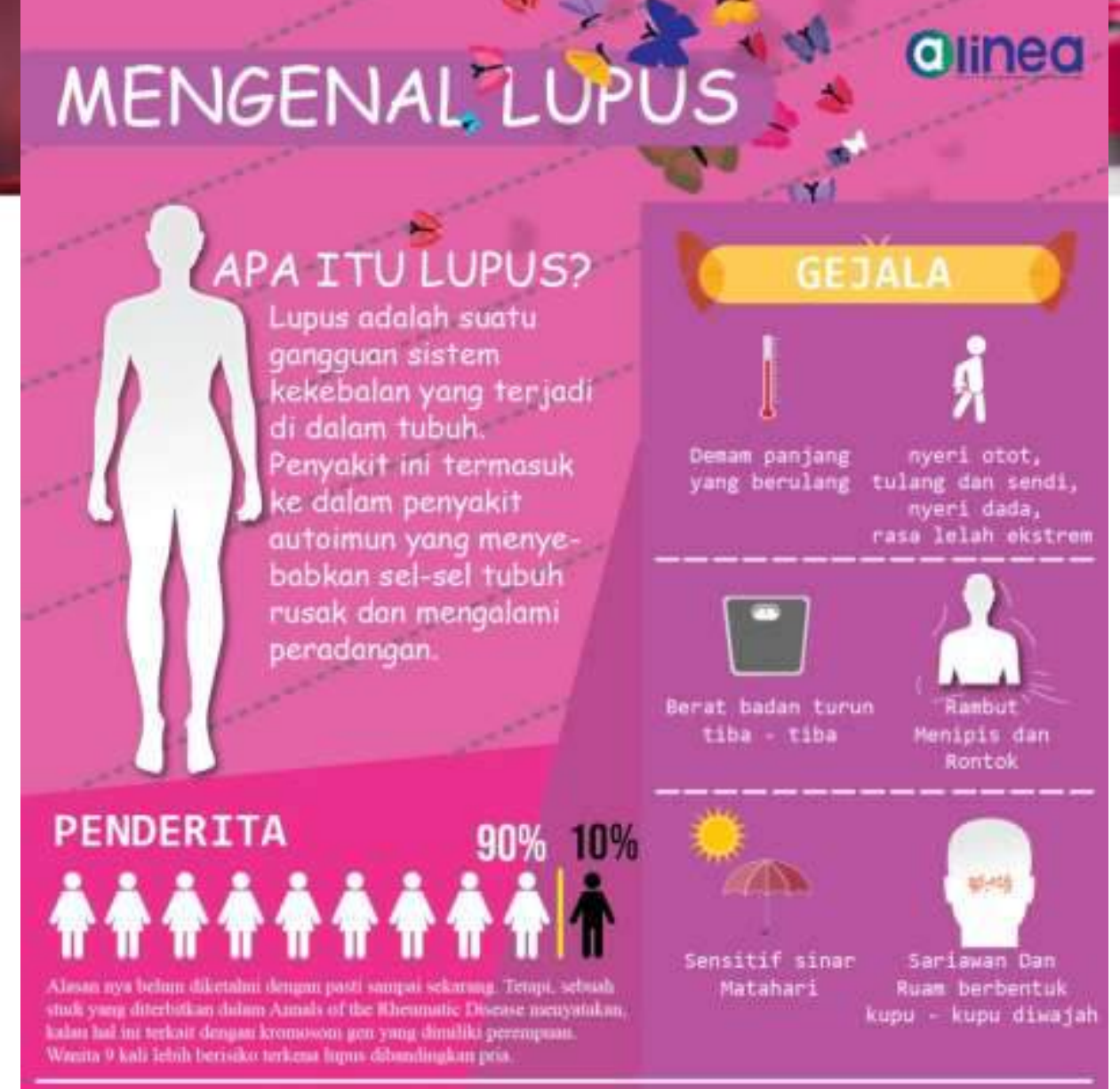

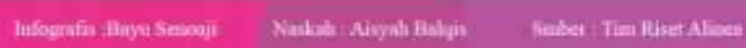


- membantu sel tumor untuk menghindar dari dikenali dan dirusak oleh sel $\mathrm{T}$

- sistem imun dapat bereaksi berlebihan (imunoproliferatif) dalam bentuk reaksi hipersensitivitas (alergi)

- Antigen yang dikenal sebagai alergen dapat menghasilkan reaksi alergi

- Alergen ini dapat berupa makanan, obat, serbuk sari, debu, kosmetik, tanaman, atau minyak tumbuhan.
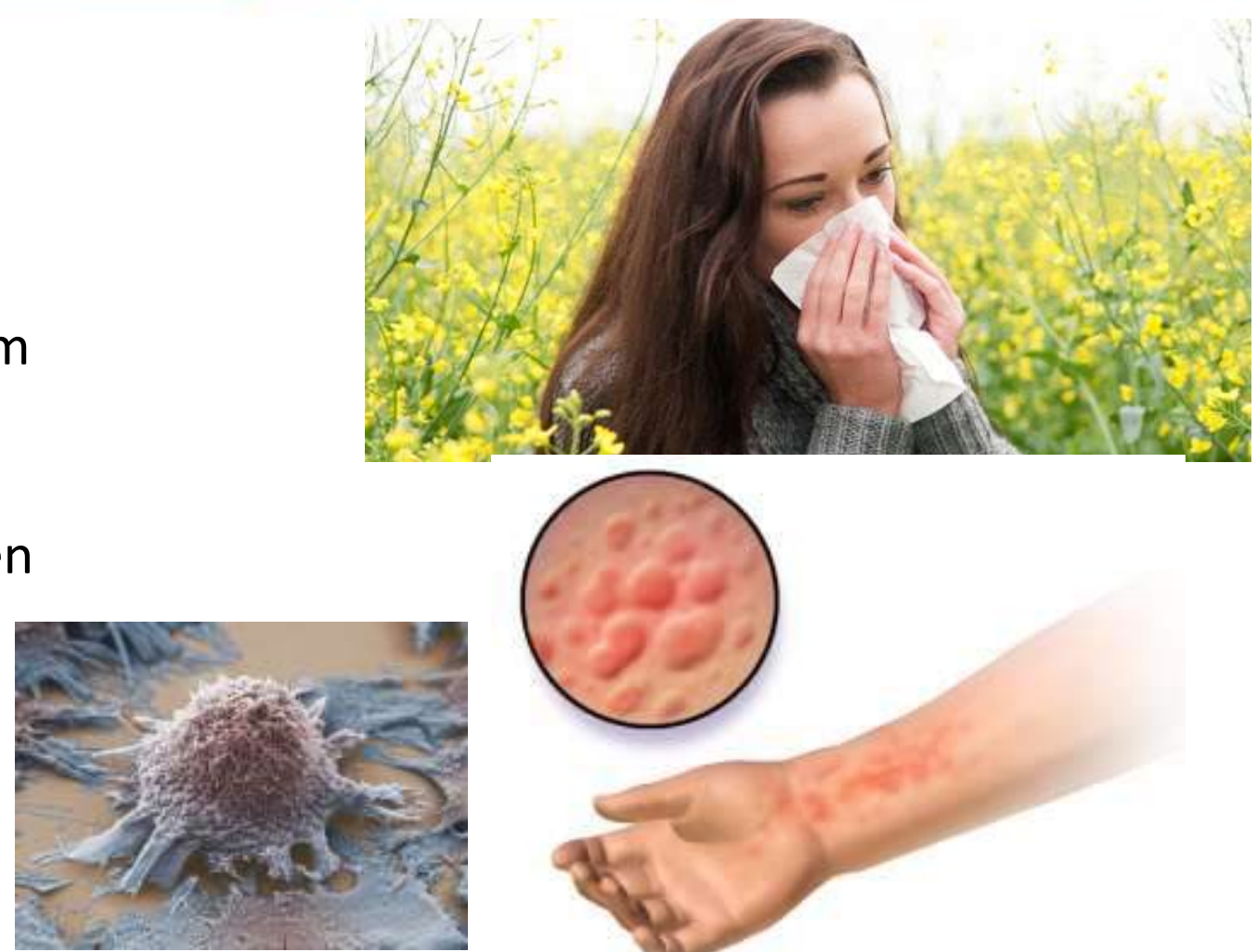


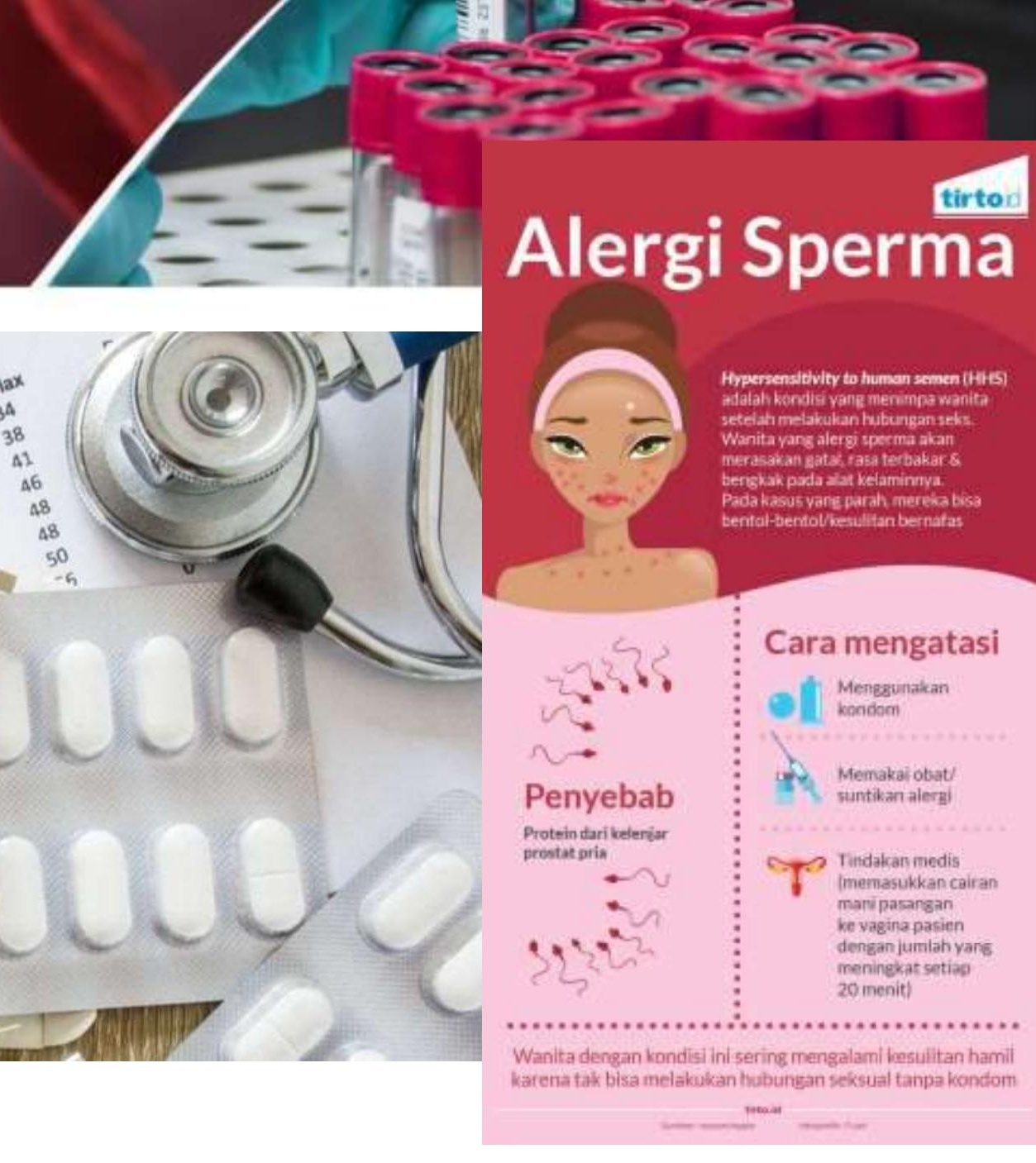



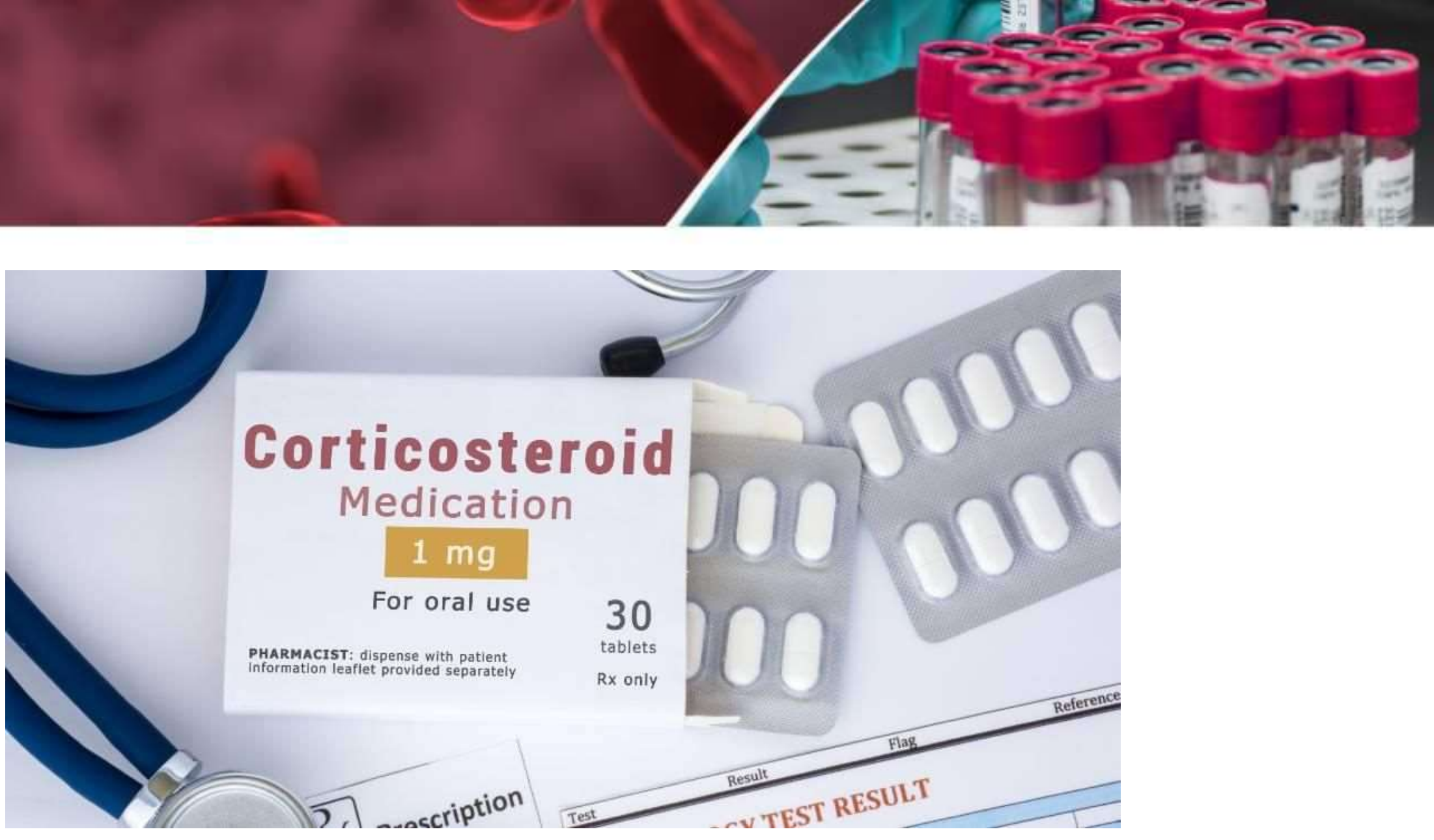


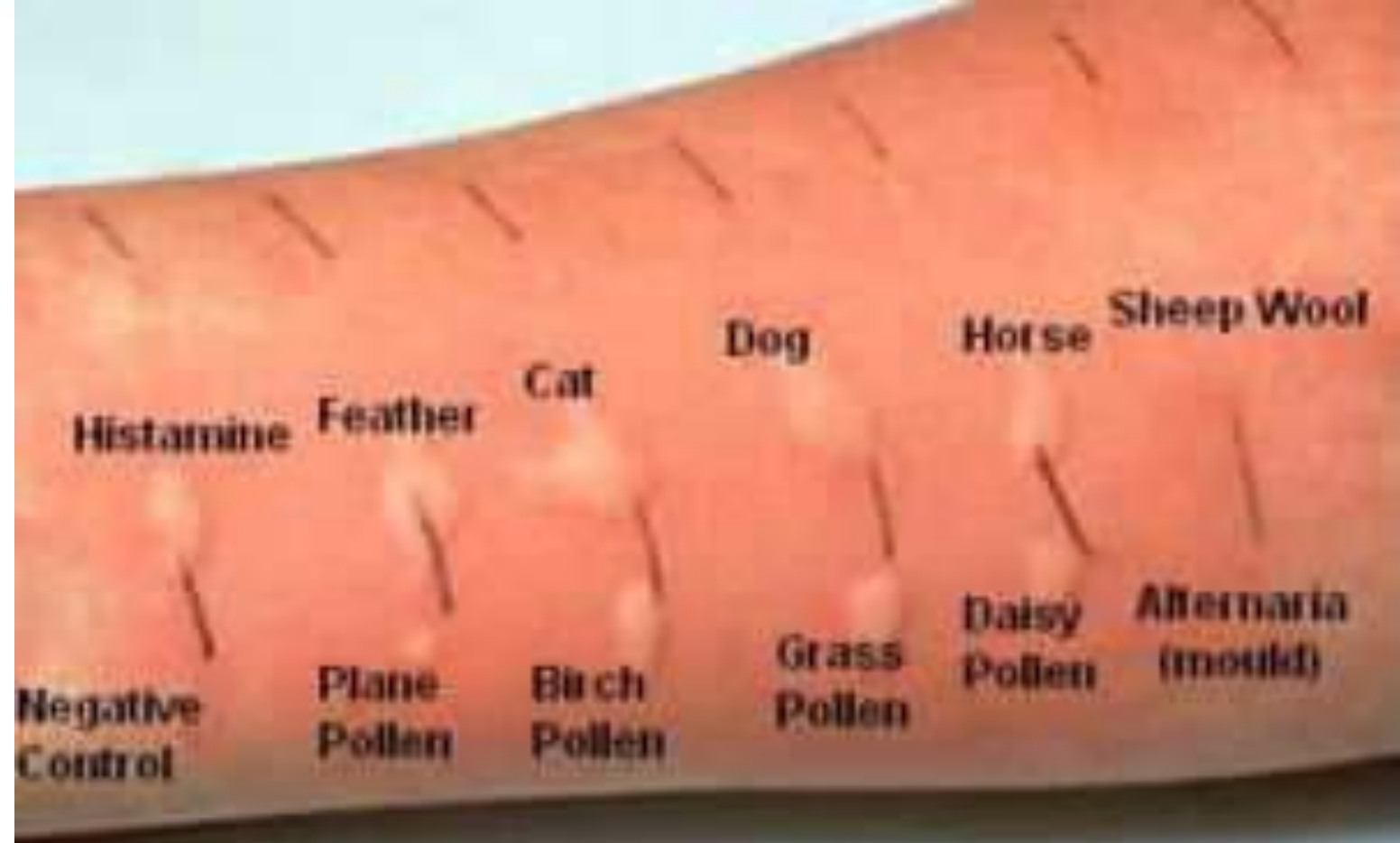




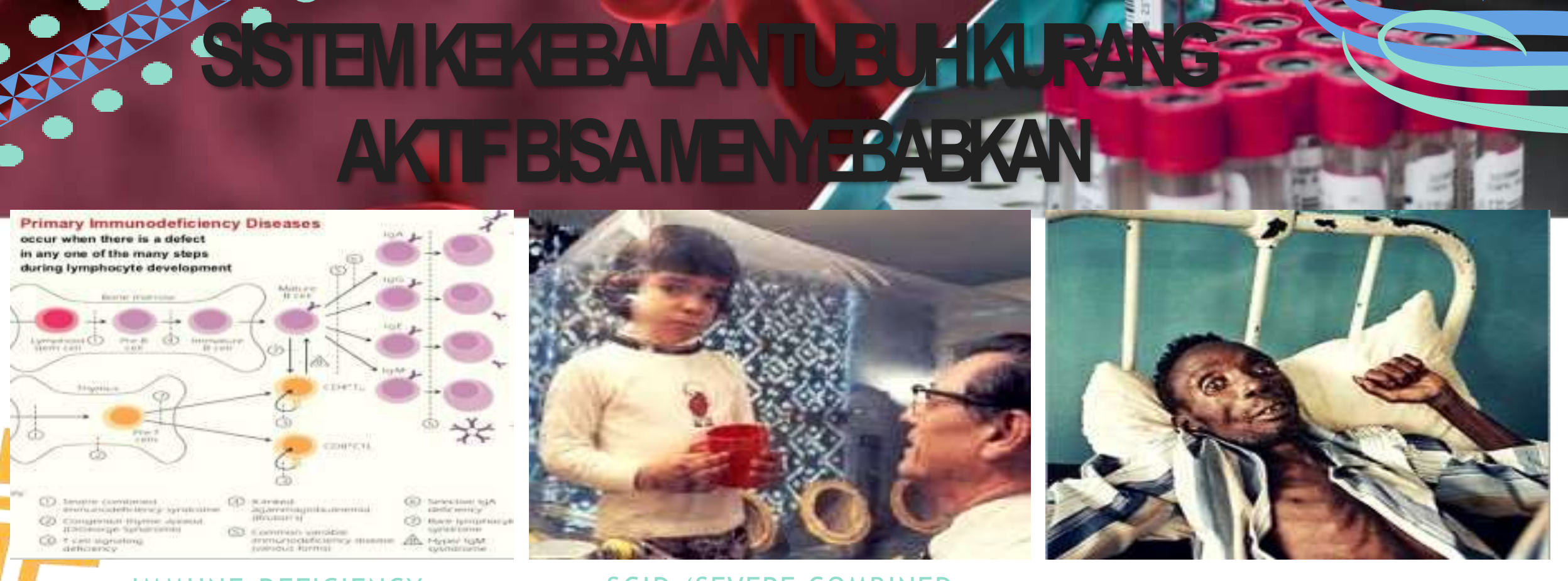




\section{Mastheniar Gravis \\ Penyakit autoimun kronis dari transmisi}

neuromuskular yang menghasilkan kelemahan otot. Ter

terputusnya komunikasi antara saraf dan otot.

\section{Thymus Displasia}

Cacat lahir di mana anak-anak yang lahir tanpa kelenjar timus, adalah contoh dari penyakit T-limfosit primer. Kelenjar timus adalah tempat limfosit $\mathrm{T}$ normal dewasa.

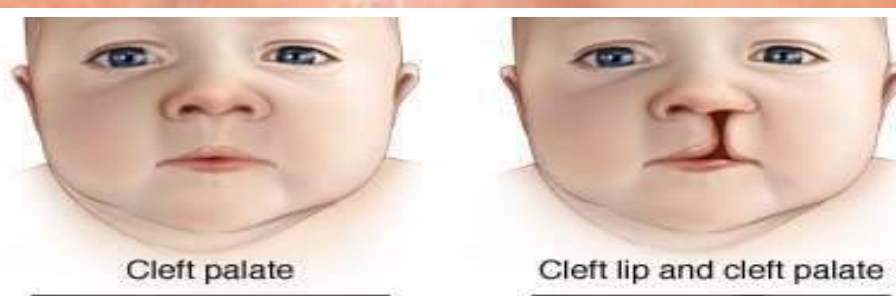

\section{Shediak-Higashi Syndrome}

Penyakit granulomatosa kronis keduanya melibatkan ketidakmampuan untuk

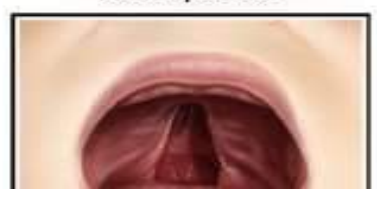

Cleft lip and cleft palate
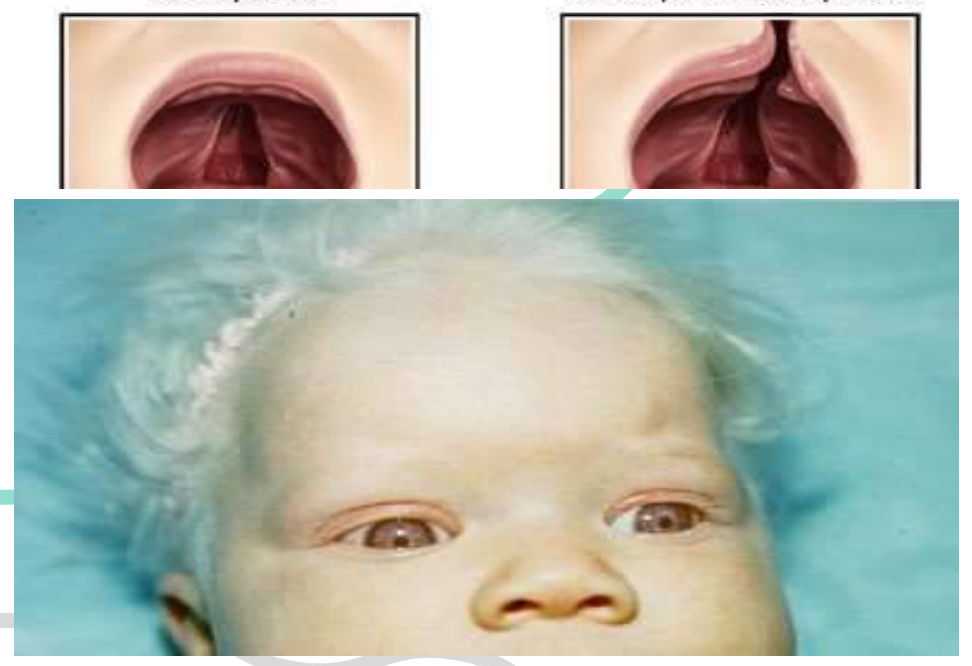


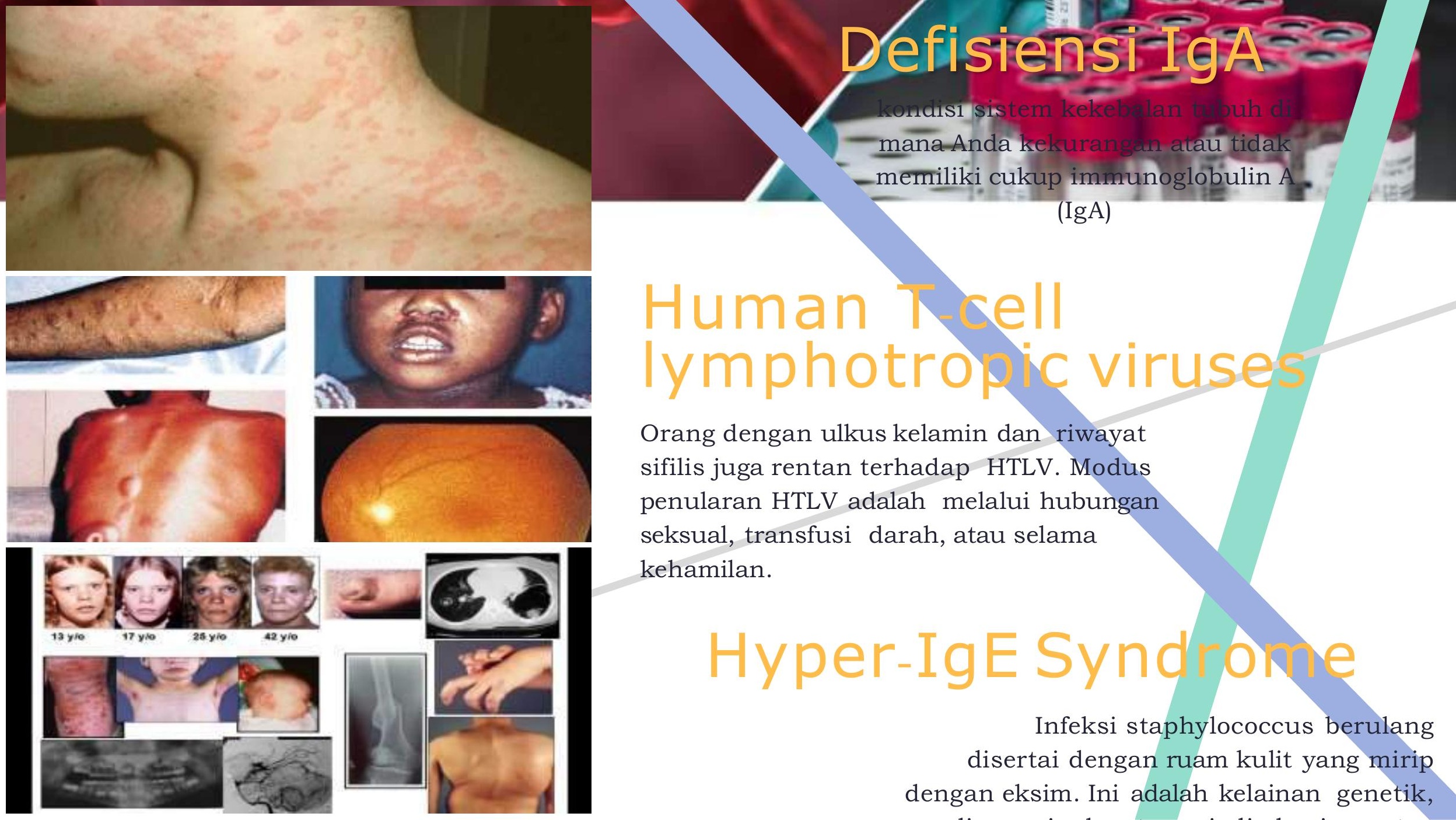




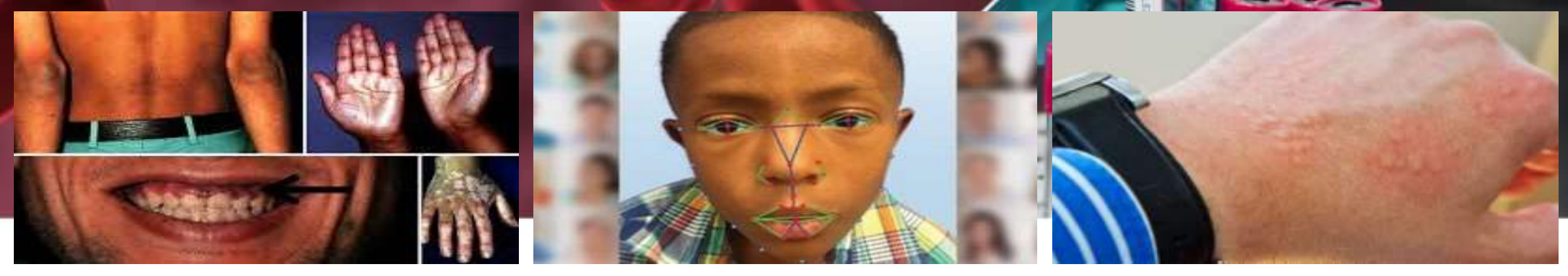

\section{ADDISON'S DISEASE}

Antibodi yang menyerang kelenjar adrenalin. Hal ini mengakibatkan tubuh kehilangan berat badan, kadar gula darah menurun, mudah lelah, dan pigmentasi kulit meningkat.

\section{HYP ER IGM SYNDROME}

Penyebab penyakit ini adalah gen di T-sel yang rusak. Karena kecacatan ini, sel B tidak mendapatkan sinyal untuk menghasilkan antibodi IgA dan IgG, dan dengan demikian akan terus memproduksi antibodi $\lg \mathrm{M}$.

\section{ALERGI}

Suatu respons imun yang berlebihan terhadap suatu senyawa yang masuk ke dalam tubuh. Senyawa yang dapat menimbulkan alergi disebut alergen. Alergen dapat berupa debu, serbuk sari, gigitan serangga, rambut kucing, dan jenis makanan tertentu misal udang. 


\section{TUGAS:}

1.Tugas kelompok Buatlah poster dengan ukuran A3 tentang

Group 1. Morfologi,Karakteristik, fungsi/peran dan mekanisme aktifasi makrofag serta contoh kasus. Group 2. Morfologi,Karakteristik, fungsi/peran dan mekanisme aktifasi Sel T serta contoh kasus Group 3. Morfologi,Karakteristik, fungsi/peran dan mekanisme aktifasi Sel B serta contoh kasus Group 4. Mutasi Sel dan Kromosom serta penyakit yang ditimbulkan akibat mutasi tersebut Group 5. fungsi dan peran vaksinasi bagi ibu dan anak

DEADLINE : 4 MEI 2020

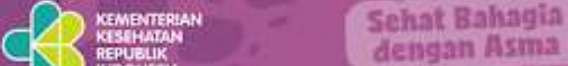

\section{Fabtor Pencetur Asma \\ Faktor pencetus adalah faktor yang dapat memicu timbulnya Asma yang tidak selalu sama untuk setiap individu penderita Asma.}

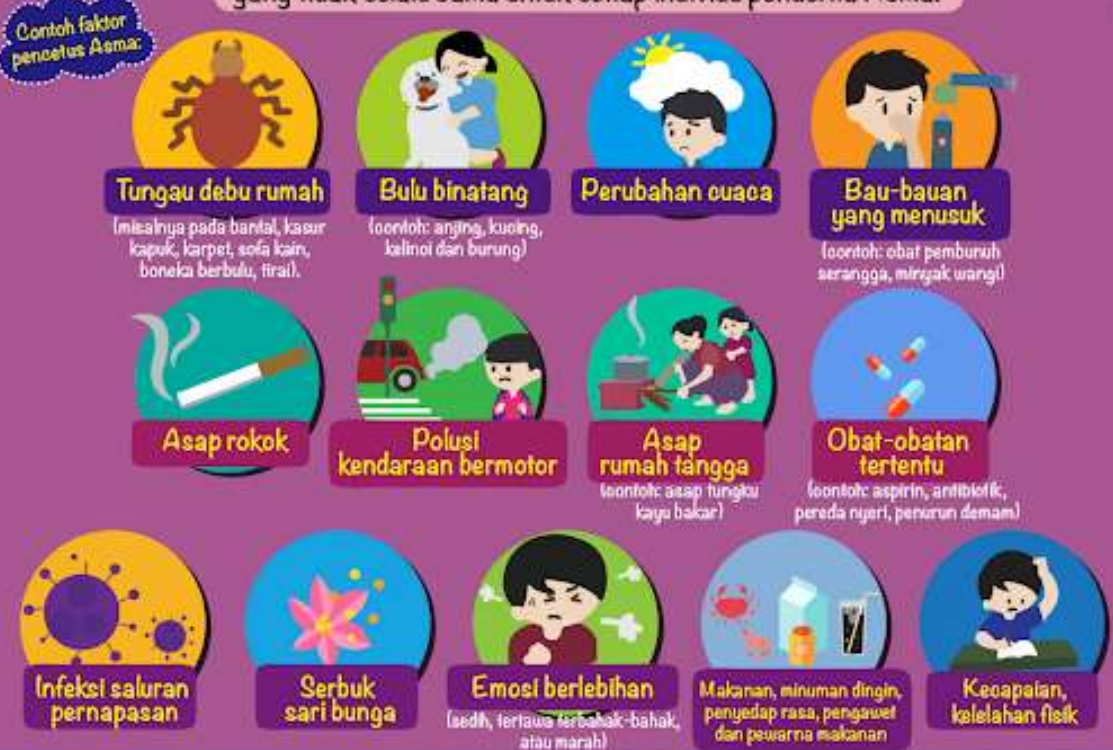


